\title{
Role of Polyamines in Efficiency of Norway Spruce (Hurst Ecotype) Somatic Embryogenesis
}

\author{
J. Malá1, M. Cvikrová2, P. Máchová1 and L. Gemperlová ${ }^{2}$ \\ ${ }^{1}$ Forestry and Game Management Research Institute, Jiloviště \\ 2Institute of Experimental Botany, Academy of Sciences of the Czech Republic, Praha \\ Czech Republic
}

\section{Introduction}

Somatic embryogenesis is considered as to be an advantageous methodology for plant micropropagation in vitro, particularly for conifers. It offers, moreover, a row of possibilities to study developmental processes during the embryo differentiation, and it enables also more detailed analyses of the mechanisms of embryo conversion.

Somatic embryogenesis can be divided into several stages, which are comparable to the stages in zygotic embryogenesis (Atree \& Fowke, 1993). However, since somatic embryos develop without the protective environment of the surrounding maternal tissue, there is a need to supply developing embryos both the nutrients and the regulatory compounds exogenously. Induction and continuous proliferation requires the auxins and the cytokinins, whereas the further growth and maturation of embryos depends on the abscisic acid (Attree et al., 1991). By the end of the maturation stage, all structures of the embryo are morphologically fully developed (Find, 1997) but the embryo becomes biochemically mature after a desiccation processing (Flinn et al., 1993).

Somatic embryogenesis in some coniferous species provides sufficient numbers of fully developed embryos usable for propagation. On the other hand, the yield of converted somatic embryos in other species is often too low for practical applications (Igasaki et al., 2003). In some instances, the successful somatic embryogenesis is a question of the selection of responsible clones within the range of a coniferous species. Research of somatic embryogenesis in conifers has increased rapidly since the eighties of the last century. Promising results were achieved especially with Norway spruce (Picea abies (L.) Karst.), in which the successful regeneration of complete plants was obtained (Attree \& Fowke, 1993; Bornman, 1985; Chalupa, 1985; Chalupa et al., 1990; Hakman et al., 1985; Malá et al., 1995). The process of somatic embryogenesis in Norway spruce can be divided into four stages characterized by the different degree of embryonic tissue differentiation: the induction of embryogenic tissue, the proliferation of somatic embryos, maturation, and finally, the conversion of mature embryos into complete plants.

The induction of embryogenic tissues can be achieved by applying phytohormones on mature or immature zygotic embryos. The initiation rate is higher when immature zygotic 
embryos are used; however, it is difficult to determine an optimal cone harvest time (Chalupa, 1985). The transfer of embryogenic tissue from proliferation onto maturation medium leads to the induction of embryo development. Despite of the successful protocol for establishment of Norway spruce somatic embryogenesis technique, there is a lack of data concerning the endogenous composition of biologically active compounds both in somatic and zygotic embryos. Generally, the development of embryos as well as their conversion into complete plantlets is closely associated with changes in endogenous phytohormone levels. Changes in endogenous hormone levels (IAA, ABA, and ethylene) during Norway spruce somatic embryo development and maturation have been recently reported (Vágner et al., 2005).

Beside the key roles of auxins and cytokinins, very important function during growth and differentiation of plant tissues belongs to polyamines (PAs) (Mattoo et al., 2010; Vera-Sirera et al., 2010). PAs have a wide spectrum of action with some similarities with plant phytohormones. In cooperation with auxins and cytokinins, PAs modulate morphogenetic processes (Altamura et al., 1993). From this point of view PAs could be considered as new category of plant hormones acting particularly as regulators of such processes as gene expression, cell proliferation, cell wall formation, etc. (Cohen, 1998). PAs are involved also in the transmission of cellular signals. They regulate the synthesis of nitric oxide, which is known as a plant signaling molecule (Besson-Bard et al., 2008).

PAs are small polycationic molecules with several amino groups, which are ubiquitous in both prokaryotes and eukaryotes (Cohen, 1998; Tiburcio et al., 1997). Also the mechanisms of PAs synthesis, transport, and catabolism are conserved from bacteria to animals and plants (Kusano et al., 2008; Tabor \& Tabor, 1984). Most of the biological functions of PAs can be explained by their polycationic nature, which allows interactions with anionic macromolecules such as DNA, RNA, and with negative groups of cellular membrane components. The synthesis of PAs within various plant tissues depends on a great variety of physiological growth regulatory stimuli as well as on various external influences as periodicity or stressing conditions (humidity, droughts), and environmental damaging factors, too.

PAs are essential compounds for life. Decrease or arrest of internal PA production inhibits a row of cellular functions, e. g. cell growth. Therefore, in the case of PAs deficiency, plant cells are equipped with a high efficient system for transfer and functional utilization of PA molecules from external sources (Cohen, 1998, Hanfrey et al., 2001, Kusano et al., 2008).

Three commonly occurring PAs in plants are diamine putrescine (Put), triamine spermidine $(\mathrm{Spd})$ and tetramine spermine (Spm). All these compounds are present in the free form or as conjugates with other low molecular substances (e. g. phenolic acids) or macromolecules (proteins, nucleoproteins). They are found in cell walls, vacuoles, mitochondria, chloroplasts and cytoplasm (Kaur-Sawhney et al., 2003). PAs are detected in increased amounts within actively differentiating and growing plant tissues. Also their activity increases mainly in growing plant tissues, during embryogenesis, root formation and stem elongation, fruit development and ripening, and during response to abiotic and biotic stress factors, too (Kumar et al., 1997).

Polyamines play a fundamental role in the regulation of somatic and zygotic embryogenesis (Kong et al., 1998; Silveira et al., 2004). The role of PAs during in vivo and in vitro 
development, including somatic embryogenesis, were recently reviewed (Baron \& Stasolla, 2008). The accumulation of high levels of PAs in somatic embryos contributes to their reserve consisting predominately of proteins and triglycerides, which are utilized during embryo germination. PAs changes were studied in embryogenic cultures of Picea abies (R. Minocha et al., 1993; Serapiglia et al., 2008; Vondráková et al., 2010), Picea rubens (R. Minocha et al., 1993), Pinus taeda (Silveira et al., 2004), and P. radiata (R. Minocha et al., 1999). Polyamine profiles in germinating somatic embryos derived from long term cultivated embryogenic mass and germinating zygotic embryos of Norway spruce were studied by Gemperlová et al. (2009). There are also several reports indicating the participation of PAs in somatic embryo development of some coniferous species (R. Minocha et al., 1999; Santanen \& Simola, 1992; Silveira et al., 2004) but the mechanism of how polyamines regulate cell differentiation processes is not fully elucidated up to the present.

Norway spruce is the most important forest tree species in the Czech Republic, both economically and due to its representation. However, only few populations can be regarded autochthonous. These populations are irreplaceable in the future, not only for maintenance and natural regeneration of the biotope, but also as an important source of genetic material needed for the breeding programs which are aimed to preserve the valuable forest sources for the future generations. The Hurst ecotype of Norway spruce is considered to be autochthonous and it is rarely preserved at the altitudes over $700 \mathrm{~m}$. Reproduction of these populations is really difficult due to the high age of the trees and longer and lengthening flushing intervals. For conifers and mainly for Norway spruce, micropropagation technologies, mainly somatic embryogenesis, represent very suitable methods of reproduction and preservation of valuable genotypes.

The aim of this study was to compare PA levels during development of somatic embryos of high responsible AFO 541 cell line with less responsible cell lines derived from the Hurst ecotype of Picea abies. The results obtained could help to a better understanding of PAs function in regulation of plant tissue differentiation processes and contribute to improving the micropropagation of less responsible Hurst Norway spruce by somatic embryogenesis.

\section{Experimental part}

\subsection{Materials and methods}

\subsubsection{Cell lines}

Picea abies (L.) Karst. embryogenic cultures of high responsible cell line AFO 541 (AFOCEL, Nangis, France) and five less responsible cell lines (L10, L13, L16, L17, L28) derived from a $P$. abies Hurst ecotype were used.

\subsubsection{Hurst cell lines initiation}

Immature cones of 140 years old elite open pollinated Hurst Norway Spruce growing in the conservation area Labské Pískovce (Northern Bohemia, CR) were collected in late July 2006 and stored at $4{ }^{\circ} \mathrm{C}$. To induce embryogenic tissue differentiation, the immature embryos extirpated from sterilized seeds ( $1 \% \mathrm{NaClO}$, Savo, Biochemie, CR) were cultivated in darkness at $24^{\circ} \mathrm{C}$ on the modification of solid E medium (Gupta \& Durzan, 
1986) with $0.2 \mathrm{mg} . \mathrm{l}^{-1}$ gelerit (Sigma-Aldrich, Germany) and phytohormones (0.5 mg.1-1 of BAP, 1.0 mg.1-1 of 2,4-D, and $0.5 \mathrm{mg} . \mathrm{l}^{-1}$ of $\left.\mathrm{Kin}\right)$, $\mathrm{pH}$ adjusted to 5.8 prior to the medium autoclaving (Malá, 1991).

In a preliminary experiment the embryogenic capacity (i.e. the ability of the ESM to produce mature somatic embryos) were determined in 45 cell lines of Hurst Norway Spruce ESM. Five of them, with diverse characteristics, were further selected for the subsequent experiments.

\subsubsection{Induction of proliferation}

The cultures of embryogenic mass were after $4 \mathrm{wks}$ of induction transferred onto fresh $\mathrm{E}$ medium of the same composition and cultured in the same conditions as previously. The embryogenic cultures were maintained by subculturing weekly.

\subsubsection{Maturation of somatic embryos}

After 12 wks of cultivation on proliferation medium were the cultures transferred onto maturation medium (solid E medium without phytohormones, supplemented with $8 \mathrm{mg} . \mathrm{l}^{-1}$ of ABA (Sigma, Chemical Co., USA) and 20 mg.l-1 of PEG (m. w. 3350, Sigma, Chemical Co., USA). Cultures were kept in same conditions as described above and subcultured every week. After $2 \mathrm{wks}$, the somatic embryo cultures were transferred onto solid E medium containing $0.1 \mathrm{mg} . \mathrm{l}^{-1}$ of IBA (Sigma Chemical Co., USA) and $20 \mathrm{mg} \cdot \mathrm{l}^{-1}$ of PEG and cultured under white fluorescent light $\left(30 \mu \mathrm{mol} \cdot \mathrm{m}^{-2} \cdot \mathrm{s}^{-1}\right)$ and $16 \mathrm{~h}$ photoperiod. After 3-4 wks the somatic embryos were harvested for desiccation.

\subsubsection{Desiccation}

Only the fully developed embryos were desiccated. The embryos were carefully transferred on the dry paper in small Petri dishes $(3 \mathrm{~cm}$ in diameter). Open dishes were placed into large Petri dishes $(18 \mathrm{~cm}$ in diameter) with several paper layers wetted by sterile water Large Petri dishes were covered by lids and sealed by parafilm. They were kept under the light regime of 12 hours of light and 12 hours of darkness, at $20 \pm 1{ }^{\circ} \mathrm{C}$ for 2 wks.

\subsubsection{Material for biochemical analyses}

The contents of PAs were determined in the course of somatic embryo development. The samples were immediately frozen in liquid nitrogen and stored at $-80{ }^{\circ} \mathrm{C}$ until determination.

\subsubsection{Polyamine analysis}

The cells were ground in liquid nitrogen and extracted overnight at $4{ }^{\circ} \mathrm{C}$ with $1 \mathrm{ml}$ of $5 \%$ perchloric acid (PCA) per $100 \mathrm{mg}$ fresh weight tissue. 1,7-Diaminoheptane was added as an internal standard, and the extracts were centrifuged at $21000 \times g$ for $15 \mathrm{~min}$. PCA-soluble free PAs were determined in one-half volume of the supernatant. The remaining supernatant and pellet were acid hydrolysed in $6 \mathrm{M} \mathrm{HCl}$ for $18 \mathrm{~h}$ at $110{ }^{\circ} \mathrm{C}$ to obtain PCA- 
soluble and PCA-insoluble conjugates of PAs as described by Slocum et al. (1989). Standards (Sigma-Aldrich, Prague, Czech Republic) and PCA-soluble free PAs, and acid hydrolysed PA conjugates were benzoylated according to the method of Slocum et al. (1989), and the resulting benzoyl-amines were analyzed by HPLC using a Beckman chromatographic system equipped with a 125S Gradient Solvent Delivery Module, 507 Variable Mode Injection Autosampler, and 168 Diode Array Detector (Beckman Instruments, Inc., Fullerton, CA, USA). A Gold Nouveau software data system was used to collect, integrate and analyse the chromatographic data. A C18 column (Phenomenex Aqua, $5 \mu \mathrm{m}, 125 \mathrm{~A}, 250 \times 4.6 \mathrm{~mm}$, Phenomenex, Utrecht, NL) was used for the separation of polyamines. Elution was carried out at a flow rate of $0.4 \mathrm{~mL} \mathrm{~min}^{-1}$ at $45^{\circ} \mathrm{C}$. Standard sample $(5 \mu \mathrm{l}$ and $10 \mu \mathrm{l})$ was injected for a single run. The mobile phase consisted of solvent A (10\% v/v methanol) and solvent B ( $80 \%$ $\mathrm{v} / \mathrm{v}$ methanol). The gradient program (expressed as percentages of solvent A) was as follows: $0-10 \mathrm{~min}, 45 \%$ to $0 \%$; $10-30 \mathrm{~min}$, isocratic $0 \%$; $30-40 \mathrm{~min}, 0 \%$ to $45 \%$. Column was washed with $45 \%$ solvent A for 30 min between samples. Eluted polyamines were detected by UV detector at $254 \mathrm{~nm}$ by comparing of their $\mathrm{R}_{\mathrm{t}}$ values with those of standards (SigmaAldrich, Prague, the Czech Republic).

\subsubsection{Statistical analyses}

Two independent experiments were carried out. Analogous results were obtained in both experiments. Means \pm S.E. of one experiment (with 3 replicates) are shown in the figures. Data were analyzed using the Student's $t$ distribution criteria.

\subsection{Results and discussion}

Tissue culture approaches, in particular somatic embryogenesis, is considered as the advantageous technique for in vitro propagation and gene conservation of conifers. Generally, the development of embryos and their conversion into plantlets is closely associated with changes in endogenous phytohormone levels, including polyamines. Positive correlation between embryogenic capacity and total content of free PAs confirmed to a crucial role of PAs (with Spd predominating, Figs 1, 2, 3) during somatic embryo development in Picea as previously described (Gemperlová et al., 2009; S.C. Minocha \& Long, 2004). On transfer from proliferation to maturation medium the levels of Put and Spd in the culture of highly responsible cell line AFO 541 were almost equal while in less responsible cultures of Hurst ecotype significantly higher levels of Put than Spd were determined as is apparent from the Put/Spd ratios in the embryogenic suspensor masses (ESM) of six cell lines of Norway spruce (AFO 541 and five of Hurst ecotype) grown on solid proliferation medium (Figs 1, 2). The contents of Put, Spd and Spm in highly responsible cell line AFO 541 steadily increased during maturation from ESM until early cotyledonary stage (Fig. 3). This stage of embryo development was characterized by very high Spd contents. On the contrary to Put and Spd, the level of Spm significantly increased during the desiccation phase (Fig. 3). The increase in Spm level in this phase might result from "certain" abiotic stress in the course of desiccation. The decline in PA contents in mature embryos was probably due to the increased catabolism of Put and Spd during the later stages of embryo development, as previously described in Picea abies (Santanen \& Simola, 1992). 


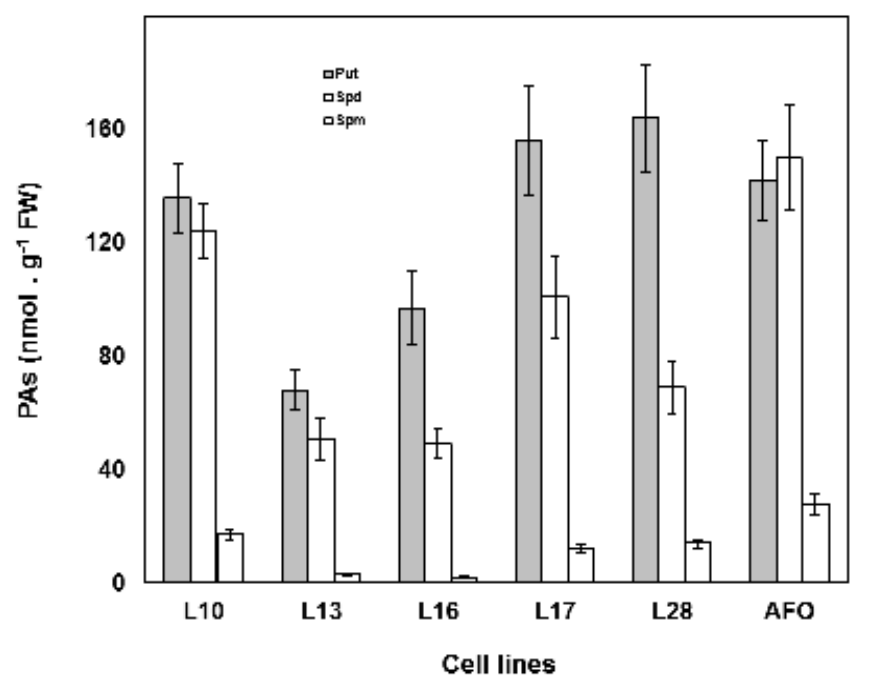

Fig. 1. Comparison of the contents of free putrescine (Put), spermidine (Spd) and spermine (Spm) in the ESMs of six cell lines of Norway spruce (AFO 541 and five of Hurst ecotype) grown on solid proliferation medium (before transfer to maturation medium). Bars represent SE of three replicates. ESM, embryogenic suspensor mass.

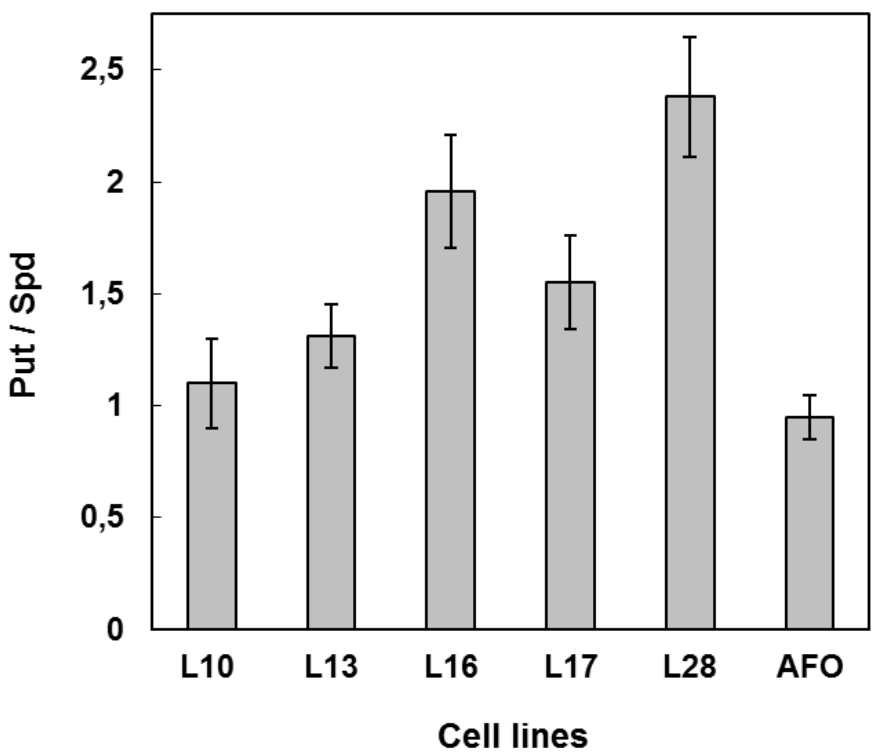

Fig. 2. Comparison of putrescine/spermidine (Put/Spd) ratios in the ESMs of six cell lines of Norway spruce (AFO 541 and five of Hurst ecotype) grown on solid proliferation medium (before transfer to maturation medium). Bars represent SE of three replicates. ESM, embryogenic suspensor mass. 


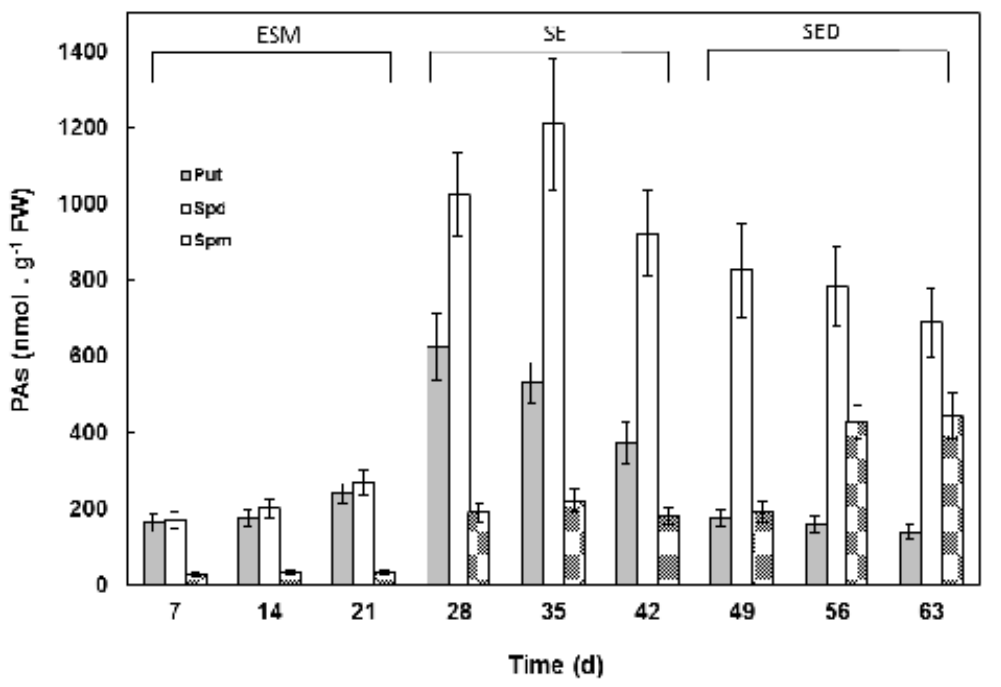

Fig. 3. Changes in cellular levels of free putrescine (Put), spermidine (Spd) and spermine (Spm) during Norway spruce (AFO 541) somatic embryo development from proliferation to desiccation. Bars represent SE of three replicates. ESM, embryogenic suspensor mass; SE, somatic embryo; SED, somatic embryo during desiccation; d, days.

Parallel rises in the content of Spd occurred during the 6 weeks of embryo development of Hurst ecotype cell lines. At this stage of somatic embryo development the predominant PA was Spd followed by Put (Fig. 4), although the mature embryos of highly responsible cell line AFO 541 contained still significantly higher level of Spd. Cell line AFO 514 and Hurst ecotype cell line L10 were characterized by high content of Spd and represented plant material with stable rapid growth during proliferation and a huge yield of somatic embryos was obtained at the end of maturation of cell line L10 (Fig. 5). On the contrary, rather low yield of less matured embryos was found in the remaining studied cell lines of less responsible ecotypes (L16 and L28) which contained lower level of Spd (Fig. 6). However, a high level of free PAs is not the only important PA-related factor in somatic embryogenesis, and (for instance) it has been proposed that an inadequate Spd/Put ratio may be causally linked to abnormal growth and disorganized cell proliferation of grape somatic embryos with high free PA contents (Faure et al., 1991). Less matured somatic embryos and lower yield of embryos in the remaining studied cell lines L13 and L17 (in comparison with the yield of embryos in the cell line L10) might coincide with the inadequate Put/Spd ratio determined in the embryos. 


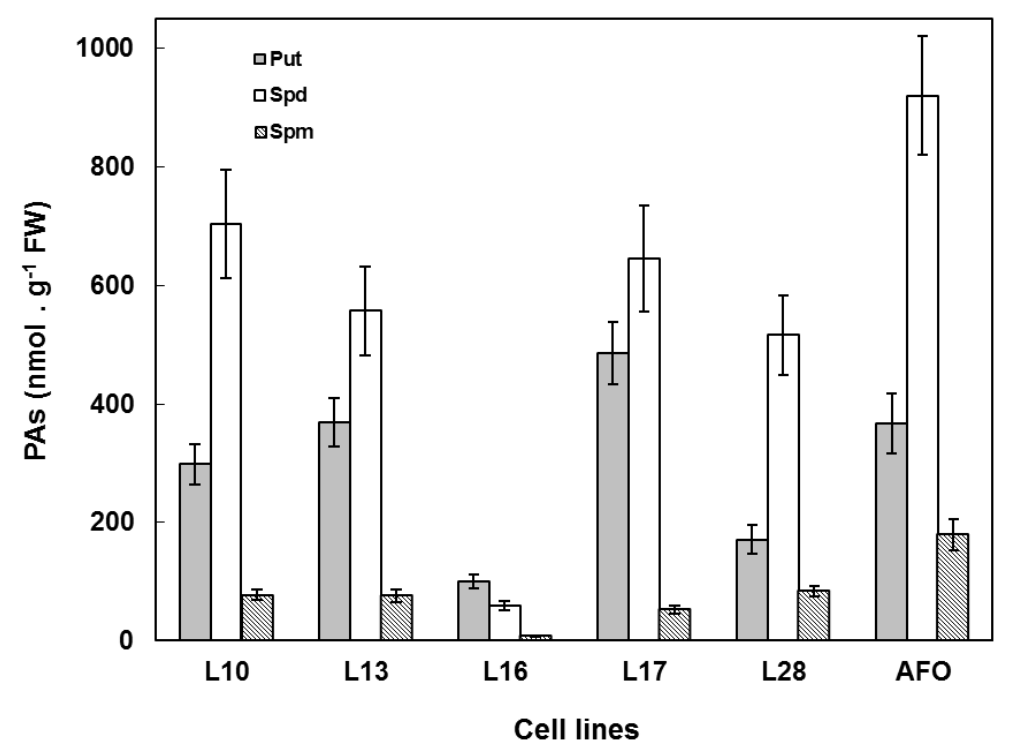

Fig. 4. Comparison of the contents of free putrescine (Put), spermidine (Spd) and spermine (Spm) in 6 week-old somatic embryos of six cell lines of Norway spruce (AFO 541 and five of Hurst ecotype) grown on solid maturation medium.

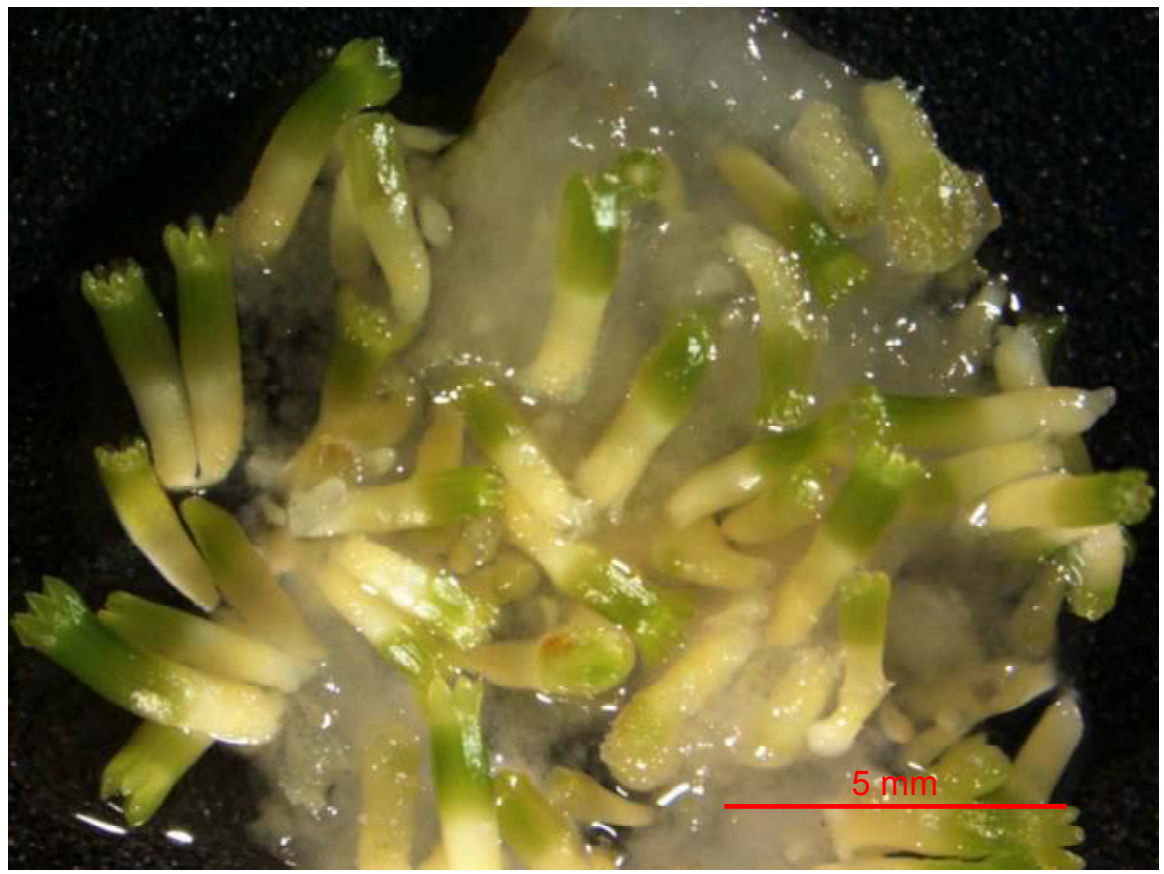

Fig. 5. Mature somatic embryos (6 week-old) of Hurst ecotype of Norway spruce L10. 


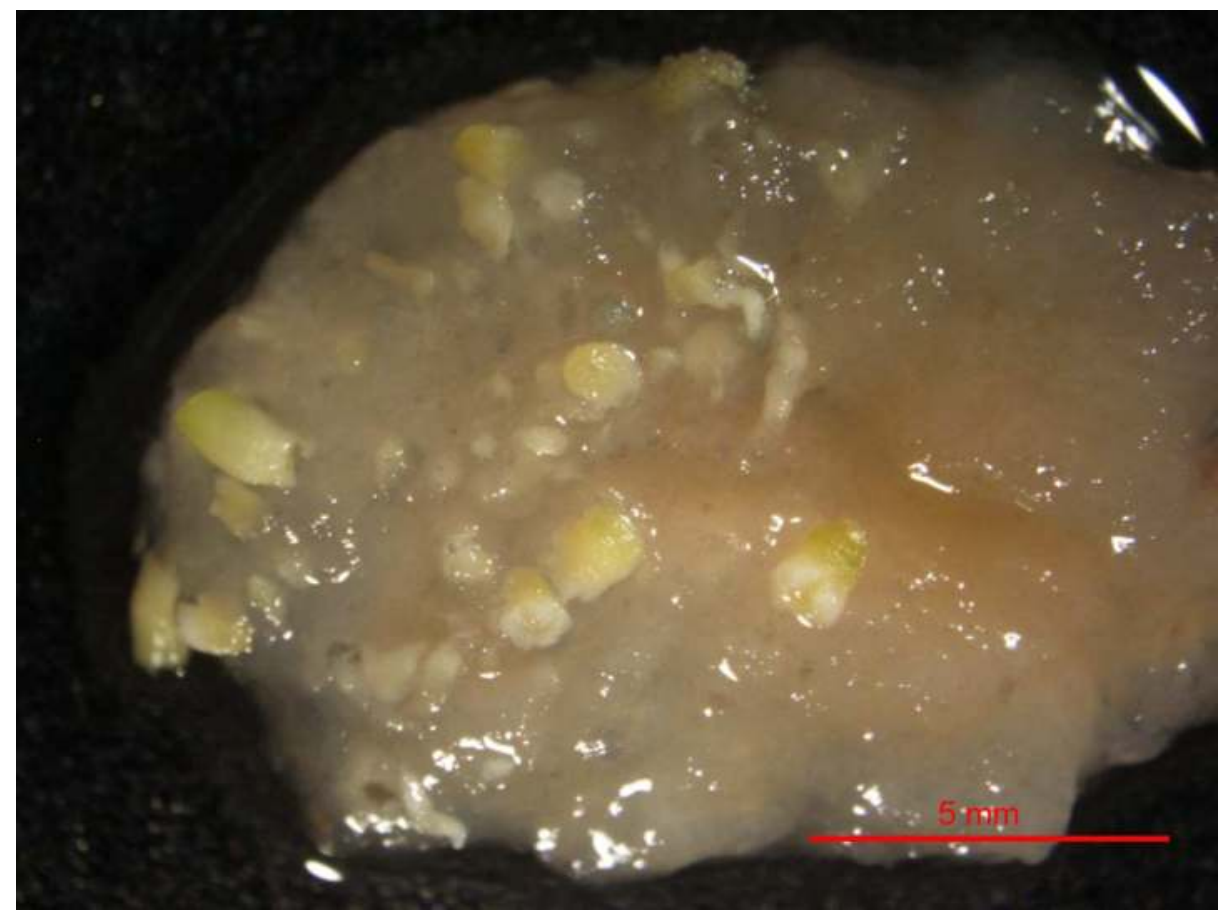

Fig. 6. Mature somatic embryos (6 week-old) of Hurst ecotype of Norway spruce L28.

Similarly, contents of PAs (higher Spd than Put levels) could be used as criteria for the physiological characterization of somatic embryogenesis in Pinus nigra Arn. (Noceda et al., 2009). Furthermore, the important role of cellular levels of metabolically active free PAs, especially contents of Spd, was shown to be essential for preservation of embryogenic potential of Norway spruce cultures after cryopreservation (Vondráková et al., 2010). The formation of somatic embryos in tissue cultures of wild carrot seemed to be also associated with high Spd level and much more Spd than Put was found in torpedo stage of these embryos (Mengoli et al., 1989). Especially Spd was implicated in somatic embryogenesis in tissue cultures of Vigna aconitifolia (Kaur-Sawhney et al., 1985), Hevea brasiliensis (El Hadrami \& D'Auzac, 1992) and in the development of globular pro-embryos in alfalfa (Cvikrová et al., 1999). However, it is not always Spd, which is the dominant polyamine in somatic embryos of conifers. Putrescine was the most abundant PA in the embryogenic suspension culture of Pinus taeda (Silveira et al., 2004), whereas the development of both somatic and zygotic embryos of Pinus radiata was characterized by high level of Spd and its concentration positively correlated with the embryo development (R. Minocha et al., 1999). High level of Put was determined in pro-embryogenic tissue of Picea rubens, while Spd was predominant during embryo development in this culture (S.C. Minocha \& Long, 2004).

As we have already mentioned in the Introduction, embryo maturation and low germination frequencies are main limitations for a broader use of somatic embryogenesis in practice. Requirement of exogenous phytohormones for efficient somatic embryogenesis is well established. Exogenously supplied polyamines might therefore 
affect and improve the induction and somatic embryo development in less responsible plant genotypes. It has been found that the exogenous application of Spd in the initiation phase significantly increased the production of embryos in Panax ginseng cultures (Kevers et al., 2000). This knowledge led as to try to improve the efficiency of somatic embryogenesis of less responsible genotypes by application of PAs into the growth medium. The studies of the possibility of improving the method of somatic embryogenesis in less responsible Hurst ecotype of Norway spruce are now in progress in our laboratory. Preliminary experiments (results not shown) reveal that low exogenous application of Put $(0.1$ and $0.01 \mathrm{mM})$ increased the number of early forms of embryos. However, on the bases of these results the effect of PA application into the growth medium in order to improve the efficiency of somatic embryogenesis of Norway spruce can not be generalized and further experiments are necessary.

The results presented here indicate a direct role for Spd and adequate Put/Spd ratio in somatic embryogenesis. Cell lines AFO 514 and L10, characterized by high content of Spd, represented plant material with stable rapid growth during proliferation and a huge yield of somatic embryos was obtained at the end of maturation. Less matured somatic embryos and rather low yield of embryos in the remaining studied cell lines (L13, L16, L17 and L28) might coincide with the lower level of Spd and/or inadequate Put/Spd ratio determined in these embryos.

\section{Conclusion}

Micropropagation technologies represent a powerful tool for improvement and acceleration of tree breeding programs in forestry. Tissue culture approaches, in particular somatic embryogenesis, hold considerable promise for breeding programs of coniferous trees. Utilization of somatic embryogenesis could facilitate reproduction of rare or selected coniferous genotypes. Despite the availability of a successful protocol for generating Norway spruce plants using a somatic embryogenesis technique, there is a lack of data concerning the endogenous composition of biologically active compounds in somatic embryos. Beside the key roles of auxins and cytokinins, very important function in differentiation processes belongs to polyamines although the mechanism of their action is still not fully cleared. Positive correlation between embryogenic capacity and total content of free PAs confirmed crucial role of PAs during somatic embryo development.

It was shown that the predominant PAs in somatic embryos of highly responsible Hurst ecotype of Norway spruce (L10) was spermidine, while embryos of less responsible ecotype (L13, L16, L17 and L28) contained lower level of Spd and/or inadequate Put/Spd ratio. Exogenously supplied PAs might therefore affect and improve the induction and somatic embryo development in less responsible plant genotypes. The studies related to the improving of somatic embryogenesis method in less responsible Hurst ecotype of Norway spruce are now in progress in our laboratory.

\section{Acknowledgments}

The authors acknowledge the funding of the Ministry for Agriculture (Project number QH 82303) and Institutional Grant AV0Z 50380511. 


\section{Abbreviations}

ABA - abscisic acid, BAP - 6-benzylaminopurine, 2,4-D - 2,4 dichlorfenoxy acid, ESM embryogenic suspensor mass, IBA - indolylbutyric acid, Kin - kinetin, PAs - polyamines, Put - putrescine, Spd - spermidine, Spm - spermine

\section{References}

Altamura, M.M.; Torrigiani, P.; Falasca, G.; Rossini, P. \& Bagni, N. (1993). Morphofunctional gradients in superficial and deep tissues along tobacco stem: polyamine levels, biosynthesis and oxidation, and organogenesis in vitro. Journal of Plant Physiology, Vol. 142, pp. 543-551, ISSN 0176-1617.

Attree, S.M. \& Fowke, L.C. (1993). Embryogeny of gymnosperms:advances in synthetic seed technology of conifers. Plant Cell, Tissue and Organ Culture, Vol. 35, No. 1, pp 1-35, ISSN: 0167-6857.

Attree, S.M.; Moore, D.; Sawhney, V.K. \& Fowke, L.C. (1991). Enhanced maturation and desiccation tolerance of white spruce (Picea glauca [Moench.] Voss.) somatic embryos: effects of a nonplasmolysing water stress and abscisic acid. Annals of Botany, Vol. 68, No. 6, pp 519-525, ISSN 0305-7364.

Baron, K. \& Stasolla, C. (2008). The role of polyamines during in vivo and in vitro development. In Vitro Cellular \& Developmental Biology - Plant, Vol. 44, No. 5, pp 384-395, ISSN 1054-5476.

Besson-Bard, A.; Courtois C.; Gauthier, A.; Dahan, J.; Dobrowolska, G.; Jeandroz, S.; Pugin, A. \& Wendehenne D. (2008). Nitric oxide in plants: production and cross-talk with $\mathrm{Ca}^{2+}$ signaling. Molecular Plant, Vol. 1, No. 2, pp 218-228, ISSN 1674-2052.

Bornman, C.H. (1985). Hormonal control of growth and differentiation in conifer tissues in vitro. Biologia Plantarum, Vol. 27, No. 4-5, pp 249-256, ISSN 006-3134.

Chalupa, V. (1985). Somatic embryogenesis and plantlet regeneration from cultured immature and mature embryos of Picea abies/L./Karst. Communicationes Instituti Forestalis Cechoslovaca, Vol. 14, pp 65-90, ISSN: 1211-2992.

Chalupa, V.; Malá, J. \& Dujičková, M. (1990). Somatic embryogenesis and regeneration of spruce (Picea abies /L./Karst.) and oak (Quercus robur L.). In: „Manipulation in vitro in higher plants“, Proc. Conf. Inst. Exp. Botany, Prague, CSAS, Olomouc, CR: p. 98.

Cohen, S.S. (1998). A guide to the polyamines. pp. 1-595, Oxford university Press, New York, NY.

Cvikrová, M.; Binarová, P.; Eder, J.; Vágner, M.; Hrubcová, M.; Zon, J. \& Macháčková, I. (1999). Effect of inhibition of phenylalanine ammonia-lyase activity on growth of alfalfa cell suspension culture: alterations in mitotic index, ethylene production, and contents of phenolics, cytokinins, and polyamines. Physiologia Plantarum, Vol 107, No. 3, pp 329-337, ISSN 1399-3054.

El Hadrami, M.I. \& D'Auzac, J. (1992). Effects of polyamine biosynthetic inhibitors on somatic embryogenesis and cellular polyamines in Hevea brasiliensis. Journal of Plant Physiology. Vol. 140, pp 33-36, ISSN 0176-1617.

Find, J.I. (1997). Changes in endogenous ABA levels in developing somatic embryos of Norway spruce (Picea abies (L.) Karst.) in relation to maturation medium, 
dessication and germination. Plant Science, Vol. 128, No. 1, pp 75-83, , ISSN 01689452.

Flinn, B.S.; Roberts D.R.; Newton C.H.; Cyr D.R.; Webster F.B. \& Taylor I.E.P. (1993). Storage protein gene expression in zygotic and somatic embryos of interior spruce. Physiologia Plantarum. Vol. 89, No. 4, pp 719-730, ISSN 1399-3054.

Faure, O.; Mengoli, M.; Nougarede A. \& Bagni. N.(1991). Polyamine pattern and biosynthesis in zygotic and somatic embryo stages of Vitis vinifera. Journal of Plant Physiology, Vol. 138, pp 545-549, ISSN 0176-1617.

Gemperlová, L.; Fisherová, L.; Cvikrová, M.; Malá, J.; Vondráková, Z.; Martincová, O. \& Vágner, M. (2009). Polyamine profiles and biosynthesis in somatic embryo development and comparison of germinating somatic and zygotic ambryos of Norway spruce. Tree Physiology, Vol. 29, No. 10, pp 1287-1298, ISSN 0829-318X.

Gupta, P. K. \& Durzan, D. J. (1986). Somatic polyembryogenesis from callus of mature sugar pine embryos. Bio/technology, Vol. 4, pp 643-645.

Hakman, I.; Fowke, L.C.; Von Arnold, S. \& Eriksson, T. (1985). The development of somatic embryos of Picea abies (Norway spruce). Plant Science, Vol. 38, No. 1, pp 53-59, ISSN 0168-9452.

Hanfrey, C.; Sommer, S.; Mayer, M.J.; Burtin, D. \& Michael, A.J. (2001). Arabidopsis polyamine biosynthesis: absence of ornithine decarboxylase and the mechanism of arginine decarboxylase activity. The Plant Journal, Vol. 27, No. 6, pp 551-560, ISSN 1365-313X.

Igasaki, T.; Sato, T.; Akashi, N.; Mohri, T.; Maruyama, E.; Kinoshita, I.; Walter C. \& Shinohara, K. 2003. Somatic embryogenesis and plant regeneration from immature zygotic embryos of Cryptomeria japonica D. Don. Plant Cell Reports, Vol. 22, No. 4, pp 239-243, ISSN 0721-7714.

Kaur-Sawhney, R.; Shekhawat, N.S. \& Galston, A.W. (1985). Polyamine levels as related to growth, differentiation and senescence in protoplast-derivated cultures of Vignaaconitifolia and Avena-sativa. Plant Growth Regulation, Vol. 3, No. 3-4, pp 329-337, ISSN 0167-6903.

Kaur-Sawhney, R.; Tiburcio, A.F.; Altabella, T. \& Galston, A.W. (2003). Polyamines in plants: An overwiew. Journal of Cell and Molecular Biology, Vol. 2, No. 1, pp 1-12, ISSN 13033646.

Kevers, C.; Le Gal, N.; Monteiro, M.; Dommes, J. \& Gaspar, T. (2000). Somatic embryogenesis of Panax ginseng in liquid cultures: a role polyamines and their metabolic pathways. Plant Growth Regulation, Vol. 31, No. 3, pp 209-214, ISSN 01676903.

Kong, L.; Attree, S.M. \& Fowke, L.C. (1998). Effects of polyethylene glycol and methylglyoxal bis(guanylhydrazone) on endogenous polyamine levels and somatic embryo maturation in white spruce (Picea glauca). Plant Science, Vol. 133, No. 2, pp 211-220, ISSN 0168-9452.

Kusano, T.; Berberich, T.; Tateda, C. \& Takahashi, Y. (2008). Polyamines: essential factors for growth and survival. Planta, Vol. 228, No. 3, pp 367-381, ISSN 0032-0935.

Kumar, A.; Altabella, T.; Taylor, M. \& Tiburcio, A.F. (1997). Recent advances in polyamine research. Trends in Plant Science, Vol. 2, No. 4, pp. 124-130, ISSN 1360-1385. 
Malá, J. (1991). Organogenesis and somatic embryogenesis in Norway spruce. Communicationes Instituti Forestalis Cechoslovaca, Vol. 17, pp 59-72, ISSN: 1211-2992.

Malá, J.; Dujičková, M. \& Kálal, J. (1995). The development of encapsulated somatic embryos of Norway Spruce (Picea abies /L./Karst.). Communicationes Instituti Forestalis Bohemicae, Vol. 18, pp 59-73, ISSN: 1211-2992.

Mattoo, A.K.; Minocha, S.C.; Minocha, R. \& Handa, A.K. (2010). Polyamines and cellular metabolism in plants: transgenic approaches reveal different responses to diamine putrescine versus higher polyamines spermidine and spermine. Amino Acids, Vol. 38, No. 2, pp 405-413, ISSN 0939-4451.

Mengoli, M.; Pistocchi, R. \& Bagni, N. (1989). Effect of long-term treatment of carrot cellcultures with millimolar concentrations of putrescin. Plant Physiology and Biochemistry, Vol. 27, No. 1, pp 1-8, ISSN 0981-9428.

Minocha, R.; Kvaalen, H.; Minocha, S.C. \& Long, S. (1993). Polyamines in embryogenic cultures of Norway spruce (Picea abies) and red spruce (Picea rubens). Tree Physiology, Vol. 13, No. 4, pp. 365-377, ISSN 0829-318X.

Minocha, R.; Smith, D.R.; Reeves, C.; Steele, K.D. \& Minocha, S.C. (1999). Polyamine levels during the development of zygotic and somatic embryos of Pinus radiata. Physiologia Plantarum, Vol. 105, No. 1, pp 155-164, ISSN 1399-3054.

Minocha, S.C \& Long, S. (2004). Polyamines and their biosynthetic enzymes during somatic embryo development in red spruce (Picea rubens Sarg.) In Vitro Cellular $\mathcal{E}$ Developmental Biology-Plant, Vol. 40, No. 6, pp 572-580, ISSN 1054-5476.

Noceda, C.; Salaj, T.; Pérez, M.; Viejo, M.; Cańal, M.J.; Salaj, J. \& Rodriguez R. (2009). DNA demethylation and decrease on free polyamines is associated with embryogenic capacity of Pinus nigra Arn. cell culture. Trees - Structure and Function, Vol. 23, No. 6, pp 1285-1293, ISSN 0931-1890.

Santanen, A. \& Simola, L.K. (1992). Changes in polyamine metabolism during somatic embryogenesis in Picea abies. Journal of Plant Physiology. Vol.140, pp 475-480, ISSN 0176-1617.

Serapiglia, M.J.; Minocha, R. \& Minocha, S.C. (2008). Changes in polyamines, inorganic ions and glutamine synthetase activity in response to nitrogen avaibility and form in red spruce (Picea rubens). Tree Physiology, Vol. 28, No. 12, pp 1793-1803, ISSN 0829-318X.

Silveira, V.; Floh, E.I.S.; Handro, W. \& Guerra, M.P. (2004). Effect of plant growth regulators on the cellular growth and levels of intracellular proteins, starch and polyamines in embryogenic suspension cultures of Pinus taeda. Plant Cell, Tissue and Organ Culture, Vol. 76, No. 1, pp 53-60, ISSN 0167-6857.

Slocum, R.D.; Flores, H.E.; Galston, A.W. \& Weinstein, L.H. (1989). Improved method for HPLC analysis of polyamines, agmatine and aromatic monoamines in plant tissue. Plant Physiology, Vol. 89, No. 2, pp 512-517, ISSN 0032-0889.

Tabor, C.W. \& Tabor, H. (1984). Polyamines. Annual Review of Biochemistry, Vol. 53, pp 749790, ISSN 0066-4154.

Tiburcio, A.F.; Altabella, T.; Borrell, A. \& Masgrau, C. (1997). Polyamine metabolism and its regulation. Physiologia. Plantarum, Vol. 100, No. 3, pp 664-674, ISSN 1399-3054

Vágner, M.; Vondráková, Z.; Fischerová, L.; Vičánková, A. \& Malbeck, J. (2005). Endogenous phytohormones during Norway spruce somatic embryogenesis. Procceding COST 843 and 851 Action, Stará Lesná (28.6.-3.7.), pp. 162-164. 
Vera-Sirera, F.; Minquet, E.G., Singh, S.K.; Ljung, K., Tuominen, H., Blazquez, M.A. \& Carbonell, J. (2010). Role of polyamines in plant vascular development. Plant Physiology and Biochemistry, Vol. 48, No. 7, pp 534-539, ISSN 0981-9428.

Vondráková, Z.; Cvikrová, M.; Eliášová, K., Martincová, O. \& Vágner, M. (2010). Cryotolerance in Norway spruce and its association with growth rates, anatomical features and polyamines of embryogenic cultures. Tree Physiology. Vol. 30, No 10, pp 1335-1348, ISSN 0829-318X. 


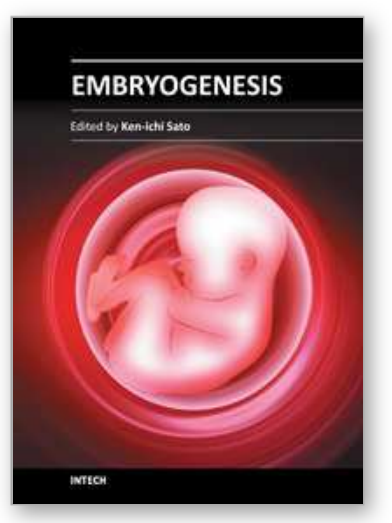

\author{
Embryogenesis \\ Edited by Dr. Ken-Ichi Sato
}

ISBN 978-953-51-0466-7

Hard cover, 652 pages

Publisher InTech

Published online 20, April, 2012

Published in print edition April, 2012

The book "Embryogenesis" is a compilation of cutting edge views of current trends in modern developmental biology, focusing on gametogenesis, fertilization, early and/or late embryogenesis in animals, plants, and some other small organisms. Each of 27 chapters contributed from the authorships of world-wide 20 countries provides an introduction as well as an in-depth review to classical as well as contemporary problems that challenge to understand how living organisms are born, grow, and reproduce at the levels from molecule and cell to individual.

\title{
How to reference
}

In order to correctly reference this scholarly work, feel free to copy and paste the following:

J. Malá, M. Cvikrová, P. Máchová and L. Gemperlová (2012). Role of Polyamines in Efficiency of Norway Spruce (Hurst Ecotype) Somatic Embryogenesis, Embryogenesis, Dr. Ken-Ichi Sato (Ed.), ISBN: 978-953-510466-7, InTech, Available from: http://www.intechopen.com/books/embryogenesis/role-of-polyamines-inefficiency-of-norway-spruce-hurst-ecotype-somatic-embryogenesis-

\section{INTECH}

open science | open minds

\section{InTech Europe}

University Campus STeP Ri

Slavka Krautzeka 83/A

51000 Rijeka, Croatia

Phone: +385 (51) 770447

Fax: +385 (51) 686166

www.intechopen.com

\section{InTech China}

Unit 405, Office Block, Hotel Equatorial Shanghai

No.65, Yan An Road (West), Shanghai, 200040, China 中国上海市延安西路65号上海国际贵都大饭店办公楼 405 单元

Phone: +86-21-62489820

Fax: +86-21-62489821 
(C) 2012 The Author(s). Licensee IntechOpen. This is an open access article distributed under the terms of the Creative Commons Attribution 3.0 License, which permits unrestricted use, distribution, and reproduction in any medium, provided the original work is properly cited. 